\title{
Antena SIW dengan Defected Ground Structure pada Frekuensi L-Band
}

\section{(SIW Antenna Using Defected Ground Structure for L-Band Frequency)}

\author{
Mia Maria Ulfah ${ }^{1}$, Achmad Munir $^{2}$
}

\begin{abstract}
In this paper, a bandwidth enhancement technique for Substrate Integrated Waveguide (SIW) antenna is attempted using Defected Ground Structure (DGS) by modifying the shape and geometry of the slot on the ground plane. In order to achieve wide bandwidth response of the antenna, a rectangular split ring incorporated with a cross shape slots are employed as DGS. The quality factor $(Q)$ of antenna increases as the substrate thickness decreases, which leads to narrow down bandwidth response of the SIW antenna. Therefore, the SIW antenna is simulated using multiple layers of FR4 epoxy dielectric substrate in overcoming the problem. The SIW antenna has a dimension of $171 \mathrm{~mm} \times 160.5 \mathrm{~mm}, 4.905 \mathrm{~mm}$-height, and is intended to work at the center frequency of $2 \mathrm{GHz}$. Furthermore, the SIW antenna is excited by proximity coupling method which is connected to a $50 \Omega$ connector. Simulation result shows that the $575 \mathrm{MHz}$ bandwidth could be achieved by the antenna with the proposed technique, in which the $-10 \mathrm{~dB}$ bandwidth response is ranged from the frequency of $1.675 \mathrm{GHz}-2.25 \mathrm{GHz}$ and the maximum gain is $6.03 \mathrm{dBi}$ at the frequency of $1.85 \mathrm{GHz}$, with bidirectional radiation pattern.
\end{abstract}

Intisari-Pada makalah ini, teknik untuk meningkatkan lebar pita pada antena Substrate Integrated Waveguide (SIW) dilakukan dengan menggunakan Defected Ground Structure (DGS) dengan cara memodifikasi bentuk dan ukuran slot tertentu pada bagian ground plane. Kombinasi antara slot split ring berbentuk persegi panjang dan slot berbentuk silang (X) sebagai DGS ditambahkan untuk mendapatkan karakteristik antena pita lebar. Substrat yang tipis dapat meningkatkan faktor kualitas $(Q)$ yang berakibat pada sempitnya lebar pita antena. Untuk mengatasi hal tersebut, antena SIW disimulasikan dengan menggunakan substrat dielektrik yang tebal. Dimensi total antena SIW adalah sebesar $171 \mathrm{~mm} \times 160,5 \mathrm{~mm}$ dengan ketebalan $4,905 \mathrm{~mm}$ dan beroperasi pada frekuensi tengah 2 GHz. Antena SIW dicatu menggunakan teknik proximity coupling

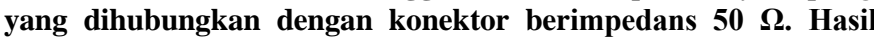
simulasi menunjukkan bahwa lebar pita sebesar $575 \mathrm{MHz}$ diperoleh antena dengan teknik yang diusulkan, dengan lebar pita -10 dB dari rentang frekuensi $1,675 \mathrm{GHz}-2,25 \mathrm{GHz}$, gain maksimum sebesar $6,03 \mathrm{dBi}$ pada frekuensi $1,85 \mathrm{GHz}$, dan pola radiasi bidirectional.

Kata Kunci-Antena, Substrate Integrated Waveguide (SIW), Defected Ground Structure (DGS), Pita Lebar, Proximity Coupling.

${ }^{1}$ Program Studi Teknik Telekomunikasi, Institut Teknologi Sumatera, Jalan Terusan Ryacudu, Desa Way Huwi, Kecamatan Jati Agung, Lampung Selatan 35365 INDONESIA (telp: 0721-8030188; e-mail: mia.ulfah@tt.itera.ac.id)

${ }^{2}$ Laboratorium Telekomunikasi Radio dan Gelombang Mikro, Sekolah Teknik Elektro dan Informatika, Institut Teknologi Bandung, Jalan Ganesha 10, Bandung 40132 INDONESIA (telp: 0222501661; e-mail:munir@ieee.org)

\section{Pendahuluan}

Seiring tren teknologi wireless yang semakin berkembang secara cepat, antena dengan karakteristik pita lebar, low profile, biaya produksi yang efisien, dan mudah terintegrasi dengan saluran planar lain sangat diperlukan untuk banyak aplikasi yang memerlukan kecepatan data tinggi. Antena Substrate Integrated Waveguide (SIW) adalah salah satu antena yang dapat memenuhi kriteria di atas terkecuali memiliki pita yang sempit. Konfigurasi antena SIW yang low profile dan faktor kualitas $(Q)$ yang tinggi menyebabkan lebar pita menjadi sempit. Faktor kualitas $(Q)$ ini bergantung pada ketebalan substrat, yaitu substrat tipis akan menghasilkan faktor kualitas yang tinggi dan berdampak pada lebar pita yang sempit [1].

Pada awalnya, metode SIW, yang diperkenalkan pada tahun 2005 [2], memiliki konstruksi mirip dengan laminated dan post-wall waveguide [3], [4]. Latar belakang penggunaan metode SIW didasari oleh kekurangan waveguide, yang meliputi ukurannya yang besar, biaya produksi yang relatif tinggi, dan tidak mudah terintegrasi dengan rangkaian planar lain, sehingga menjadikan waveguide kurang cocok untuk banyak aplikasi. Pada dasarnya, struktur SIW terdiri atas deretan tabung dari logam, atau disebut juga dengan via, yang berperan sebagai dinding waveguide. Via tersebut ditanamkan pada substrat berbahan dielektrik dengan ketebalan dan relative permittivity tertentu yang dilapisi oleh logam pada bagian atas dan bawahnya. Dengan struktur tersebut, bentuk non-planar pada waveguide dapat diimplementasikan dalam bentuk planar. Secara praktis, realisasi SIW dapat menggunakan Printed Circuit Board (PCB).

Beberapa penelitian untuk mengatasi lebar pita yang sempit pada antena SIW telah dilakukan [5]-[10]. Dengan menempatkan via di atas antena cavity SIW, lebar pita terbukti dapat ditingkatkan hingga 60\% dari lebar antena cavity SIW biasa [7]. Lebar pita antena juga dapat ditingkatkan dengan cara menghilangkan substrat pada bagian bawah slot, dengan tujuan untuk mengurangi effective permittivity dari slot, sehingga kapasitans slot menurun, yang mengakibatkan lebar pita antena dapat meningkat [8]. Teknik lainnya adalah dengan menggunakan Defected Ground Structure (DGS), yang terbukti merupakan teknik yang sederhana, tetapi efektif untuk meningkatkan kinerja antena [11]-[13]. Untuk mendapatkan antena pita lebar, slot diletakkan pada bagian patch dan ground plane [12]. DGS adalah salah satu teknik untuk meningkatkan lebar pita dengan cara memodifikasi bentuk dan ukuran slot pada ground plane. Dengan teknik DGS, diharapkan sempitnya lebar pita pada antena SIW dapat teratasi. 


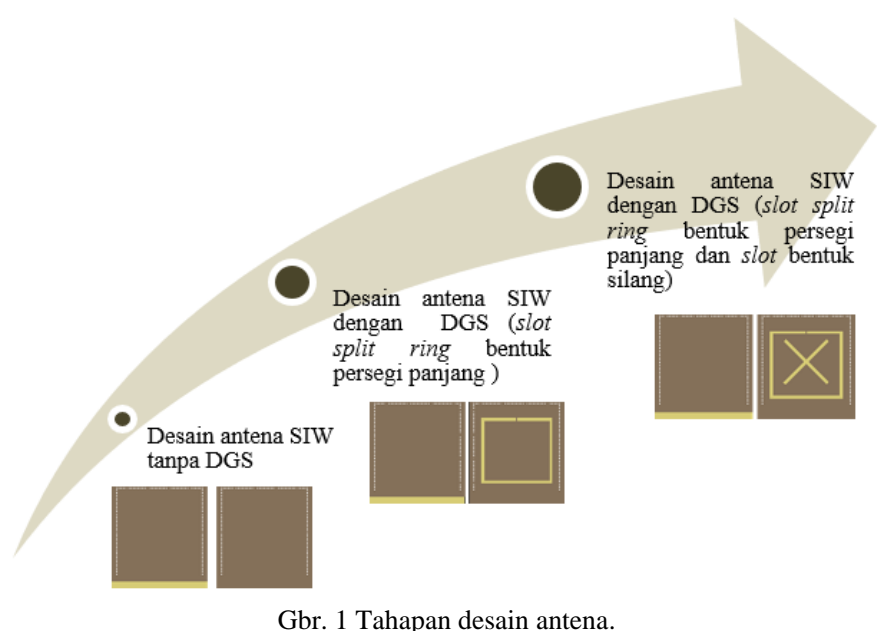

Makalah ini berisi perancangan dan simulasi antena SIW pita lebar yang beroperasi pada frekuensi $L$-band dengan frekuensi tengah $2 \mathrm{GHz}$ untuk aplikasi radar. Teknik DGS diimplementasikan dengan menggabungkan slot split ring berbentuk persegi panjang dengan slot berbentuk silang (X) pada ground plane. Kombinasi antara slot split ring berbentuk persegi panjang dengan slot berbentuk silang (X) tersebut diharapkan dapat memperlebar pita antena SIW. Antena dicatu menggunakan teknik proximity coupling dengan beberapa lapis substrat, yang saluran pencatunya berada pada substrat bagian bawah, sedangkan patch berada pada substrat bagian atas. Untuk menunjukkan pengaruh DGS dalam peningkatan lebar pita antena, kinerja antena SIW tanpa DGS dibandingkan dengan kinerja antena SIW dengan DGS seperti yang diusulkan pada makalah ini.

\section{DeSAin DAN Simulasi ANTENA SIW}

\section{A. Konfigurasi Antena}

Proses pembuatan desain antena meliputi parameterparameter yang dihitung berdasarkan persamaan matematis. Desain antena SIW ini terdiri atas tiga tahapan, yang meliputi desain antena SIW tanpa DGS, desain antena SIW dengan slot split ring berbentuk persegi panjang (dengan DGS), dan desain antena SIW dengan kombinasi slot split ring berbentuk persegi panjang dan slot berbentuk silang (X), seperti yang ditunjukkan pada Gbr. 1. Untuk desain awal, yaitu desain antena SIW tanpa DGS, digunakan desain pada penelitian sebelumnya karena desain tersebut menghasilkan antena multiband [14]. Antena multiband dapat menjadi antena dengan karakteristik pita lebar jika frekuensi resonansinya saling berdekatan. Hal tersebut dapat diwujudkan dengan memodifikasi bentuk saluran pencatu dan bentuk slot pada ground plane.

1) Antena SIW tanpa DGS: Bagian ini diawali dengan konfigurasi antena SIW tanpa DGS. Metode SIW merupakan waveguide konvensional, tetapi dalam bentuk planar.

Pada SIW terdapat mode Transverse Elecric (TE) seperti halnya pada waveguide. Pada mode $\mathrm{TE}_{\mathrm{mn}}$, dimensi SIW dapat dihitung berdasarkan frekuensi cut-off $\left(f_{c m n}\right)$, seperti pada (1), sesuai persamaan dimensi pada waveguide [15].

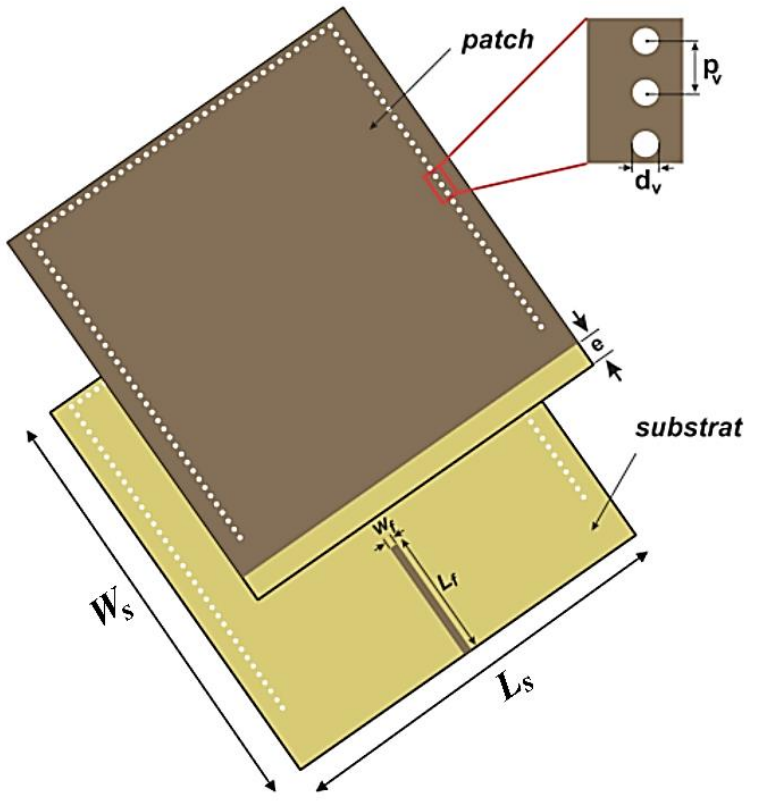

(a)
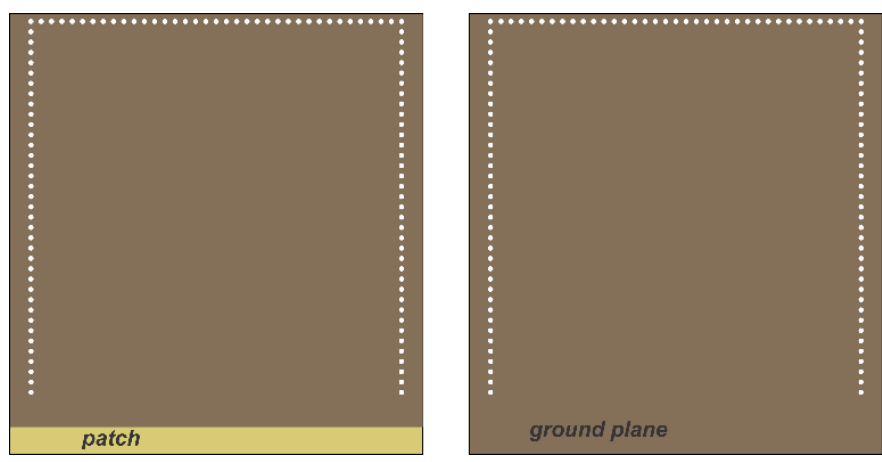

(b)

Gbr. 2 Desain antena SIW, (a) tampak penuh, (b) tanpa DGS.

$$
f_{c m n}=\frac{c}{2 \pi \sqrt{\mu_{r} \varepsilon_{r}}} \sqrt{\left(\frac{m \pi}{W_{s}}\right)^{2}+\left(\frac{n \pi}{h_{t}}\right)^{2}}
$$

dengan $W_{s}$ dan $h_{t}$ secara berurutan adalah lebar dan tinggi antena SIW, $m$ dan $n$ adalah orde, $\mu_{r}$ adalah permeabilitas substrat, $\varepsilon_{r}$ adalah permittivity substrat, dan $c$ adalah kecepatan cahaya di ruang hampa. Untuk mendapatkan antena SIW yang bekerja pada mode dominan $\left(\mathrm{TE}_{10}\right)$, lebar antena $\left(W_{S}\right)$ dapat diturunkan dari (1).

$$
W_{s}=\frac{c}{2 f_{c 10} \sqrt{\mu_{r} \varepsilon_{r}}} .
$$

Terdapat beberapa parameter penting yang harus diperhatikan dalam merancang antena SIW, antara lain diameter via $\left(d_{v}\right)$, jarak antar pusat via atau disebut pitch $\left(p_{v}\right)$, lebar efektif SIW $\left(W_{e f}\right)$, tebal substrat $\left(h_{s}\right)$, dan relative permittivity substrat $\left(\varepsilon_{r}\right)$ [16]. Jarak antara pusat via sebaris dengan pusat via baris terluar lain, atau biasa disebut lebar efektif SIW $\left(W_{e f}\right)$, diperoleh dengan menggunakan (3) [2].

$$
W_{e f}=W_{s}-1,08 \frac{d_{v}{ }^{2}}{p_{v}}+0,1 \frac{d_{v}{ }^{2}}{W_{s}} .
$$


Sementara itu, untuk mencegah rugi-rugi radiasi, pitch dan diameter via harus memenuhi (4) dan (5) [17].

$$
\begin{aligned}
p_{v} & \leq 2 d_{v} \\
\frac{d_{v}}{\lambda_{0}} & \leq 0,1
\end{aligned}
$$

dengan $\lambda_{0}$ menyatakan panjang gelombang di ruang hampa.

Dalam perancangan antena SIW ini, bahan substrat dielektrik yang digunakan adalah $F R 4$ epoxy dengan relative permittivity $\left(\varepsilon_{r}\right)$ sebesar 4,4 dan $\tan (\delta)$ sebesar 0,02 , dengan total ketebalan substrat $\left(h_{t}\right)$ sebesar $4,8 \mathrm{~mm}$. Teknik pencatuan proximity coupling direalisasikan dengan saluran mikrostrip yang dihubungkan dengan konektor yang memiliki impedans karakteristik $\left(Z_{0}\right)$ sebesar $50 \Omega$. Dengan $Z_{0}$ sebesar $50 \Omega$ dan ketebalan masing-masing substrat $\left(h_{s}\right)$ sebesar 1,6 $\mathrm{mm}$, maka perhitungan lebar saluran pencatu $\left(w_{f}\right)$ dapat menggunakan (6) [15].

$$
\frac{w_{f}}{h_{S}}=\frac{8 e^{A}}{e^{2 A}-2}
$$

dengan $A=\frac{z_{0}}{60} \sqrt{\frac{\varepsilon_{r}+1}{2}}+\frac{\varepsilon_{r}-1}{\varepsilon_{r}+1}\left(0,23+\frac{0,11}{\varepsilon_{r}}\right)$.

Pada teknik pencatuan proximity coupling, saluran pencatu tidak terhubung langsung dengan patch, melainkan dengan proses coupling medan listrik. Saluran pencatu ini terletak di sisi atas substrat bawah, seperti ditunjukkan pada Gbr. 2(a). Desain awal, yaitu desain antena SIW tanpa DGS, ditunjukkan pada Gbr. 2(b).

2) Antena SIW dengan DGS: Di bagian ini, konfigurasi antena SIW tanpa DGS dimodifikasi dengan penambahan slot pada bagian ground plane. Slot pada bagian ground plane, atau dikenal juga dengan istilah DGS, merupakan suatu teknik untuk meningkatkan lebar pita. Saluran pencatu sebagai elemen pengeksitasi mengirim gelombang ke arah ground plane dan patch sebagai radiator. Gelombang yang mengalir ke arah ground plane tersebut kemudian dipantulkan kembali ke arah radiator, tetapi saat slot diletakkan pada bagian ground plane, ground plane tidak lagi berperan sebagai reflektor sepenuhnya karena sebagian gelombang mengalami kebocoran (leaky wave) melalui slot tersebut.

Slot yang pertama ditambahkan pada bagian ground plane adalah slot split ring berbentuk persegi Panjang, seperti yang diilustrasikan pada Gbr. 3. Selanjutnya, untuk optimasi karakteristik antena, terkait nilai koefisien refleksi, slot silang berbentuk X ditambahkan seperti ditunjukkan pada Gbr. 4.

\section{B. Studi Parameter}

Studi parameter dilakukan melalui simulasi dengan bantuan perangkat lunak untuk melihat pengaruh DGS pada peningkatan lebar pita. Dalam proses optimasi dengan studi parameter ini, pada setiap perubahan suatu variabel, dimensi variabel lain disimpan sebagai nilai yang optimal.

Dari (1) dan (2) dengan frekuensi kerja yang diinginkan didapatkan ukuran lebar antena SIW awal, yaitu sebesar 44,69 mm. Berdasarkan hasil simulasi yang ditunjukkan pada Gbr. 5, dengan dimensi sesuai persamaan matematis, ternyata nilai
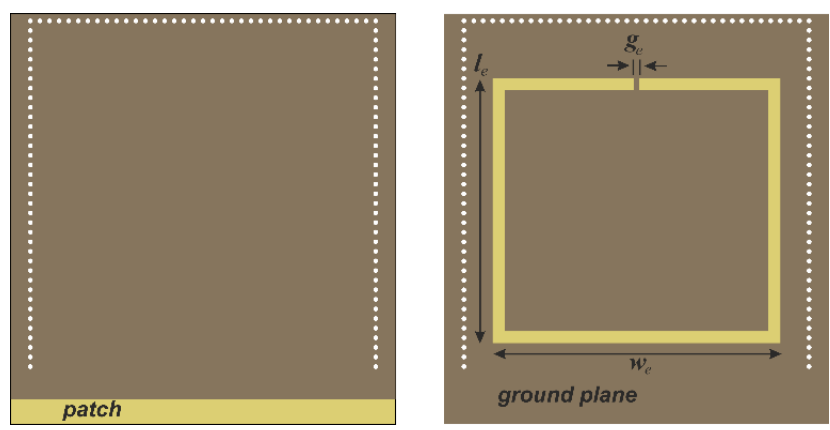

Gbr. 3 Desain antena SIW dengan slot split ring berbentuk persegi panjang.
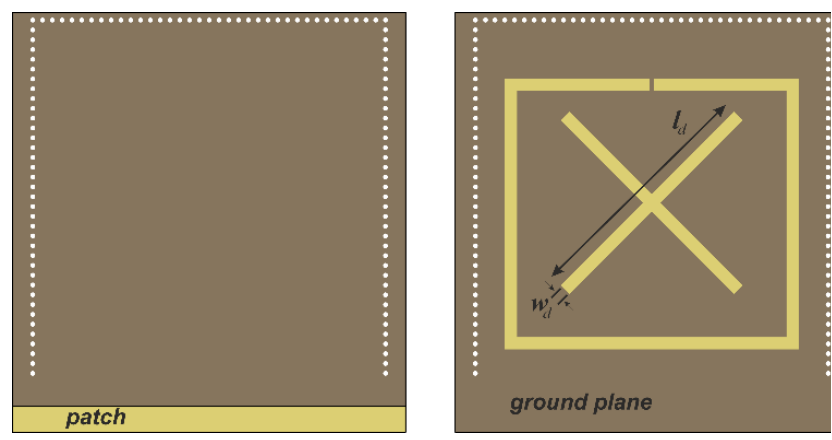

Gbr. 4 Desain antena SIW dengan kombinasi slot split ring berbentuk persegi panjang dan slot berbentuk silang.

koefisien refleksi pada frekuensi kerja belum memenuhi nilai yang diinginkan. Sesuai (1) dan (2), parameter frekuensi berbanding terbalik dengan parameter dimensi antena. Oleh karena itu, untuk menggeser nilai koefisien refleksi ke frekuensi kerja, dilakukan penambahan dimensi antena. Dimensi $171 \mathrm{~mm} \times 160,5 \mathrm{~mm}$ dipilih karena meskipun nilai koefisien refleksinya masih kurang memadai, tetapi jika dilihat dari bentuk sinyalnya, antena tersebut tergolong multiband dan tidak terjadi fluktuasi yang sangat tajam.

Jika diukur dari parameter koefisien refleksi, lebar pita merupakan daerah frekuensi yang nilai koefisien refleksinya kurang dari -10 dB. Dari hasil simulasi, antena SIW dengan dimensi $171 \mathrm{~mm}$ x 160,5 mm belum mencapai nilai koefisien refleksi kurang dari $-10 \mathrm{~dB}$ pada frekuensi yang diinginkan. Oleh karena itu, optimasi antena dengan teknik DGS diterapkan pada langkah selanjutnya untuk memperbaiki nilai koefisien refleksi yang berakibat pada pelebaran pita frekuensi antena.

Variabel pertama yang dioptimasi adalah panjang slot split ring berbentuk persegi panjang $\left(l_{e}\right)$. Panjang slot bervariasi mulai dari $90 \mathrm{~mm}, 100 \mathrm{~mm}$, sampai $120 \mathrm{~mm}$. Berdasarkan hasil simulasi pada Gbr. 6, penambahan slot split ring berbentuk persegi panjang ini dapat menurunkan nilai koefsien refleksi sampai di bawah $-10 \mathrm{~dB}$, walaupun pada daerah frekuensi tertentu masih ada nilai koefisien refleksi di atas $-10 \mathrm{~dB}$. Seperti yang ditunjukkan pada Gbr. 5, semakin panjang slot, frekuensi semakin bergeser ke kiri atau ke arah frekuensi lebih rendah. Panjang slot sebesar $120 \mathrm{~mm}$ dipilih karena nilai koefisien refleksinya relatif berada di bawah -10 dB dibandingkan dengan yang lainnya.

Setelah mendapatkan ukuran panjang slot, selanjutnya dilakukan perubahan pada lebar slot split ring berbentuk 


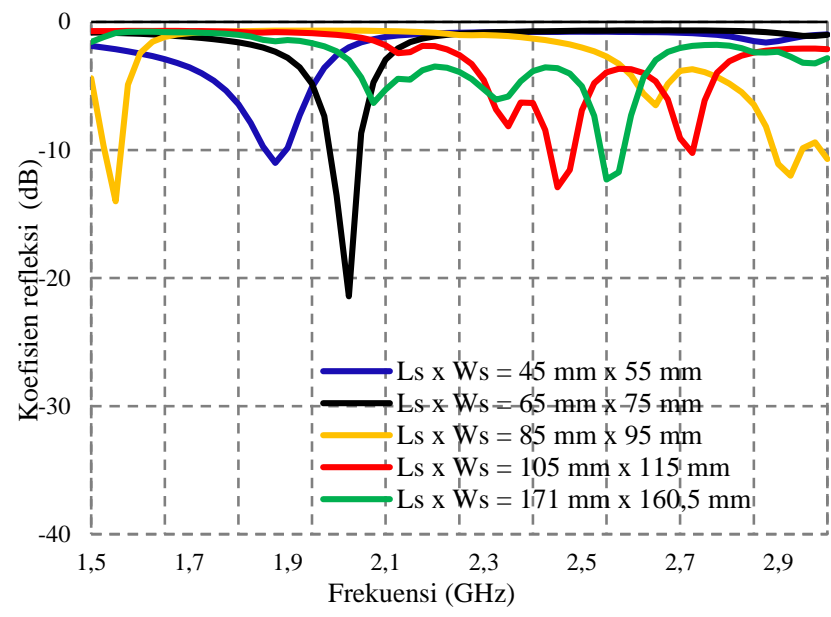

Gbr. 5 Hasil simulasi dimensi antena SIW.

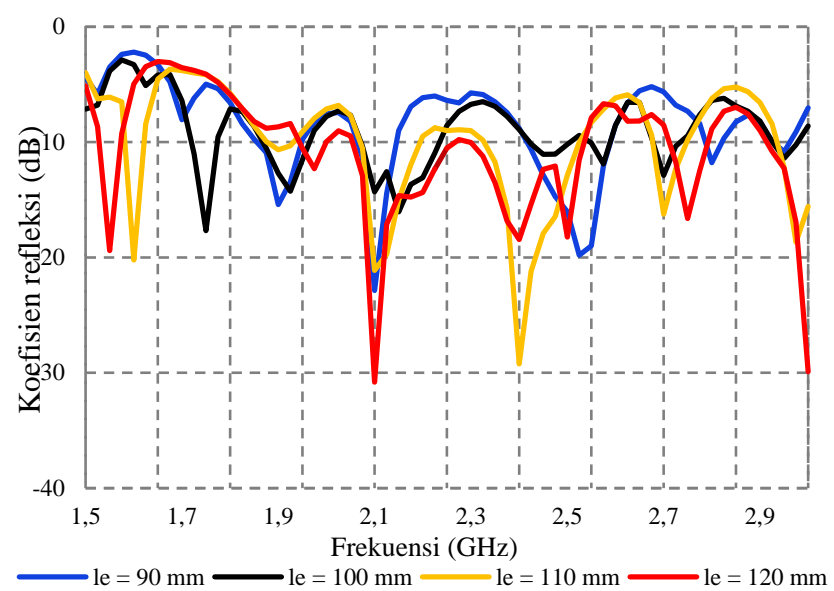

Gbr. 6 Pengaruh perubahan panjang slot split ring berbentuk persegi terhadap nilai koefisien refleksi.

persegi panjang $\left(w_{e}\right)$. Lebar slot divariasi dari $100 \mathrm{~mm}$ hingga $130 \mathrm{~mm}$ dengan interval sebesar $10 \mathrm{~mm}$. Dari hasil simulasi yang ditunjukkan pada Gbr. 7, lebar slot sebesar $110 \mathrm{~mm}$ memperoleh nilai koefisien refleksi kurang dari $-10 \mathrm{~dB}$ yang paling baik pada rentang frekuensi yang diamati dibanding ukuran lainnya. Oleh karena itu, dimensi slot split ring berbentuk persegi panjang sebesar $120 \mathrm{~mm} \times 110 \mathrm{~mm}$ dipilih untuk dilakukan optimasi selanjutnya.

Slot split ring berbentuk persegi panjang ternyata belum dapat meningkatkan lebar pita secara optimal, tetapi dapat menggeser frekuensi resonansi ke arah frekuensi yang diinginkan. Oleh karena itu, slot silang yang membentuk huruf $\mathrm{X}$ ditambahkan di bagian tengah slot split ring berbentuk persegi, dengan harapan dapat memperbaiki nilai koefisien refleksi dari studi parameter sebelumnya.

Perubahan variabel yang diamati selanjutnya adalah panjang slot bentuk silang $\left(l_{d}\right)$. Panjang slot bervariasi dari 40 $\mathrm{mm}, 60 \mathrm{~mm}, 80 \mathrm{~mm}$, dan $100 \mathrm{~mm}$, dan lebar slot diinisialisasi sebesar $5 \mathrm{~mm}$. Berdasarkan hasil simulasi yang ditunjukkan pada Gbr. 8, perubahan panjang slot berpengaruh pada pergeseran frekuensi resonansi, yaitu semakin panjang slot, frekuensi resonansi semakin bergeser ke arah frekuensi yang lebih rendah. Oleh karena itu, panjang slot sebesar $100 \mathrm{~mm}$

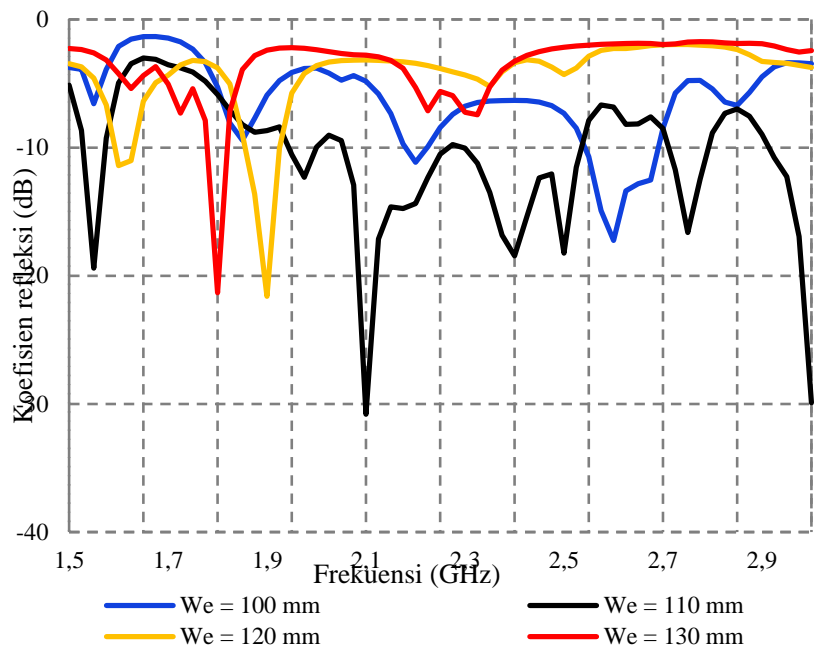

Gbr. 7 Pengaruh perubahan lebar slot split ring berbentuk persegi panjang terhadap nilai koefisien refleksi.

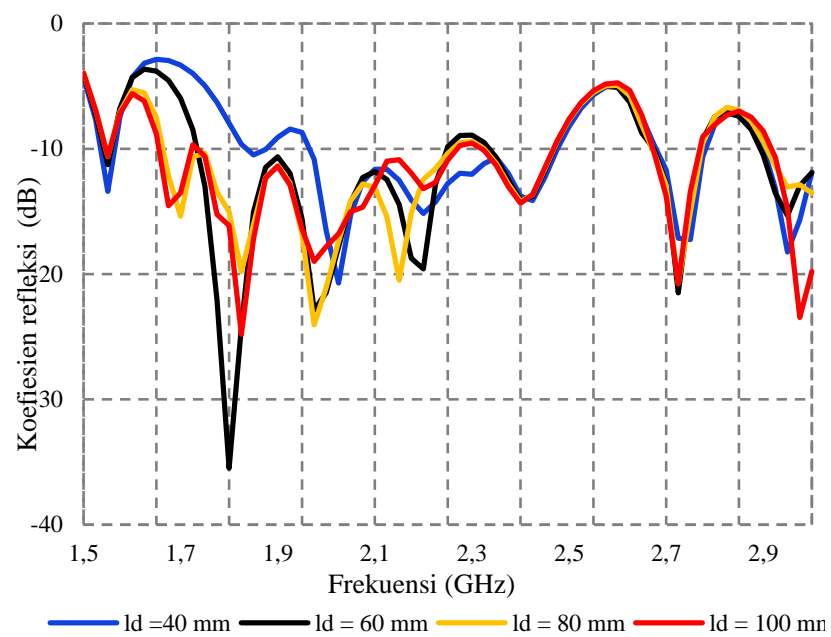

Gbr. 8 Pengaruh perubahan panjang slot bentuk silang terhadap nilai koefisien refleksi.

dipilih karena mendekati frekuensi kerja yang diinginkan dan memiliki nilai koefisien refleksi di bawah $-10 \mathrm{~dB}$ yang baik.

Parameter terakhir yang diamati adalah lebar slot yang berbentuk silang $\left(w_{d}\right)$. Lebar slot juga divariasikan mulai dari $3 \mathrm{~mm}, 5 \mathrm{~mm}, 7 \mathrm{~mm}$, dan $9 \mathrm{~mm}$. Seperti yang ditunjukkan pada Gbr. 9, semakin lebar slot, frekuensi semakin bergeser ke arah yang lebih tinggi dan nilai koefisien refleksi pada daerah frekuensi resonansi semakin turun di bawah $-10 \mathrm{~dB}$. Lebar slot sebesar $5 \mathrm{~mm}$ dipilih karena frekuensi resonansi jatuh pada frekuensi $1,675 \mathrm{GHz}$ dan nilai koefisien refleksinya cenderung di bawah $-10 \mathrm{~dB}$. Dari studi parameter pada masing-masing variabel fisik antena yang telah dilakukan, didapatkan dimensi akhir antena SIW dengan DGS yang disajikan pada Tabel I.

\section{KARAKTERISASI ANTENA}

Berdasarkan hasil studi parameter pada subbagian sebelumnya, karakteristik antena SIW tanpa DGS disbandingkan dengan karakteristik antena SIW dengan DGS, ditinjau dari parameter koefisien refleksi, gain, dan pola radiasinya. Perbandingan nilai koefisien refleksi antena SIW tanpa dan 


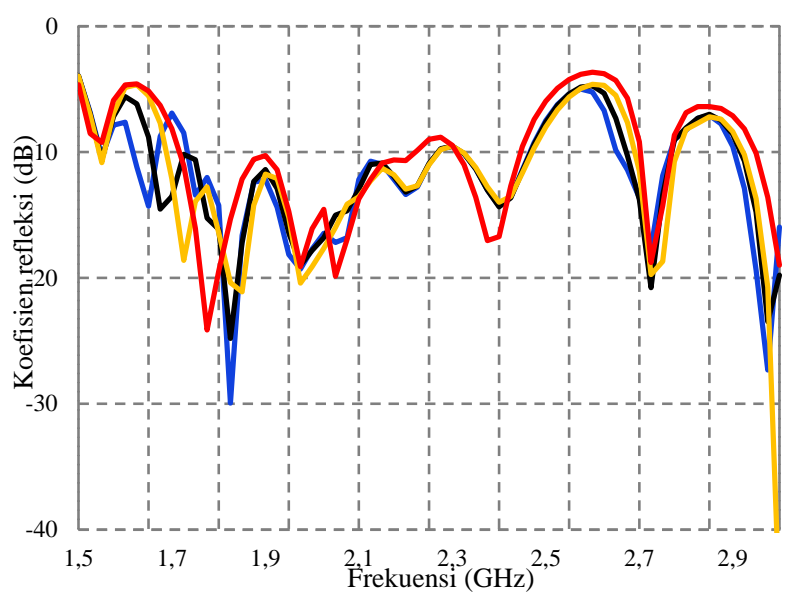

Gbr. 9 Pengaruh perubahan lebar slot bentuk silang terhadap nilai koefisien refleksi.

TABEL I

VARIABEL FIsIK DESAIN ANTENA SIW

\begin{tabular}{|l|c|}
\hline \multicolumn{1}{|c|}{ Parameter } & Nilai $(\mathbf{m m})$ \\
\hline Panjang SIW $\left(L_{\mathrm{s}}\right)$ & 171 \\
\hline Lebar SIW $\left(W_{\mathrm{s}}\right)$ & 160,5 \\
\hline Lebar patch nontembaga $(e)$ & 9,5 \\
\hline Diameter via $\left(d_{v}\right)$ & 2 \\
\hline Pitch $\left(p_{v}\right)$ & 4 \\
\hline Panjang saluran pencatu $\left(L_{f}\right)$ & 51 \\
\hline Lebar saluran pencatu $\left(w_{f}\right)$ & 1,8 \\
\hline Panjang slot split ring persegi panjang $\left(l_{e}\right)$ & 120 \\
\hline Lebar slot split ring persegi panjang $\left(w_{e}\right)$ & 110 \\
\hline Gap slot split ring persegi panjang $\left(g_{e}\right)$ & 1 \\
\hline Panjang slot bentuk silang $\left(l_{d}\right)$ & 100 \\
\hline Lebar slot bentuk silang $\left(w_{d}\right)$ & 5 \\
\hline
\end{tabular}

dengan DGS ditunjukkan pada Gbr. 10. Hasil simulasi menunjukkan bahwa antena SIW dengan DGS memiliki matching impedance yang baik, yang ditandai dengan nilai koefisien refleksi di bawah $-10 \mathrm{~dB}$ untuk rentang frekuensi $1,675 \mathrm{GHz}$ sampai $2,25 \mathrm{GHz}$, atau dengan kata lain lebar pita sebesar $575 \mathrm{MHz}$. Sementara itu, antena SIW tanpa DGS hanya menghasilkan koefisien refleksi di bawah $-10 \mathrm{~dB}$ pada rentang $2,55 \mathrm{GHz}$ sampai $2,575 \mathrm{GHz}$, atau lebar pita $25 \mathrm{MHz}$.

Jika ditinjau dari parameter gain, antena SIW tanpa DGS menghasilkan gain lebih rendah dibandingkan antena SIW dengan DGS yang menunjukkan gain di atas $5 \mathrm{dBi}$. Seperti yang ditunjukkan pada Gbr. 11, pada rentang frekuensi yang diamati, gain maksimal yang terukur adalah sebesar $6,03 \mathrm{dBi}$ pada frekuensi $1,85 \mathrm{GHz}$ untuk antena SIW dengan DGS. Pada frekuensi yang sama, antena SIW tanpa DGS menghasilkan gain sebesar -33 dBi. Hasil tersebut menunjukkan bahwa pengaruh kombinasi slot pada ground plane juga mampu memperbaiki parameter gain antena SIW.

Jika dibandingkan antara grafik parameter koefisien refleksi dengan grafik parameter gain terhadap frekuensi yang tertera pada Gbr. 10 dan Gbr. 11, antena SIW tanpa DGS memiliki nilai koefisien refleksi yang lebih kecil daripada antena SIW dengan DGS pada frekuensi sekitar 2,6 GHz. Namun, pada

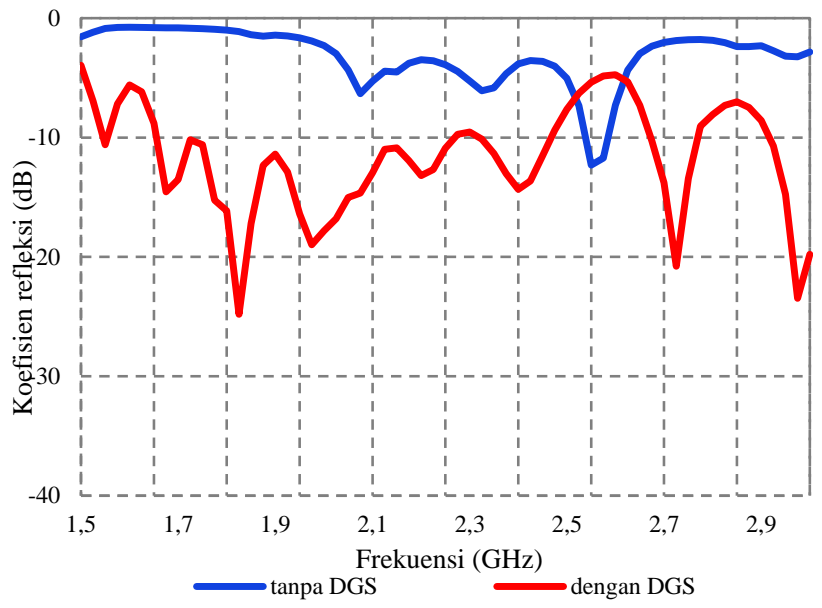

Gbr. 10 Perbandingan hasil simulasi nilai koefisien refleksi antena SIW tanpa dan dengan DGS.

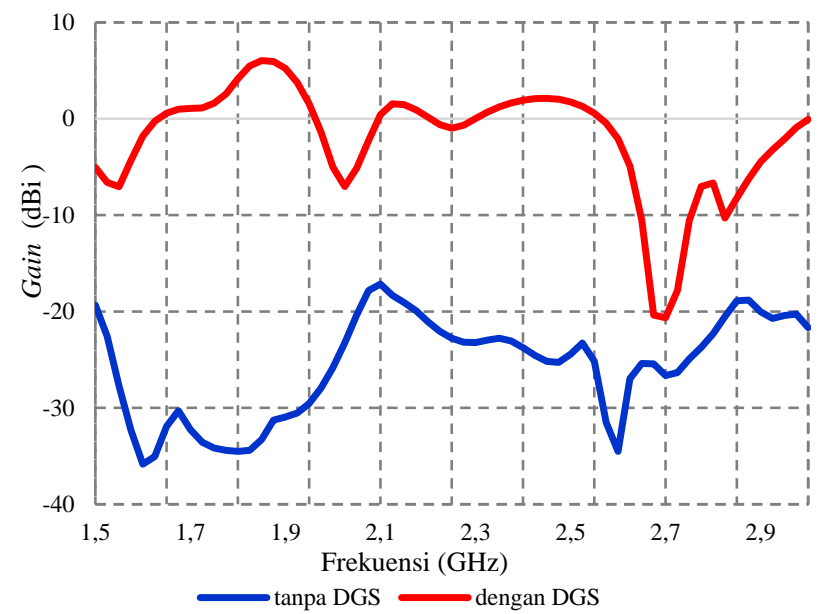

Gbr. 11 Perbandingan hasil simulasi gain antena SIW tanpa dan dengan DGS.

frekuensi yang sama, nilai gain untuk antena SIW tanpa DGS lebih rendah daripada antena SIW dengan DGS. Dengan kata lain, perbaikan parameter koefisien refleksi tidak selalu disertai perbaikan parameter gain, karena hal tersebut dapat disebabkan oleh redaman (loss) yang besar. Nilai koefisien refleksi yang semakin kecil berarti gelombang yang dipantulkan kembali ke sumber mengecil. Adapun untuk kasus antena dengan DGS, terjadi pembagian daya ke arah main lobe dan back lobe, sehingga daya yang diradiasikan arah main lobe (radiator) berkurang.

Perbaikan parameter lebar pita dan gain ternyata berpengaruh pada pola radiasi antena SIW yang dirancang. Pola radiasi antena bergantung pada bentuk, susunan, atau teknik pencatuannya. Hasil simulasi untuk pola radiasi arah azimut dan arah elevasi yang ternormalisasi ditunjukkan pada Gbr. 12 dan Gbr. 13 secara berurutan. Keberadaan slot pada ground plane menyebabkan antena memiliki pola radiasi bidirectional. Seperti yang telah dijelaskan sebelumnya, DGS menyebabkan gelombang mengalami kebocoran (leaky wave) dari arah ground plane, terlihat dari back lobe antena yang cukup besar. Akibatnya, antena yang dirancang memancarkan 


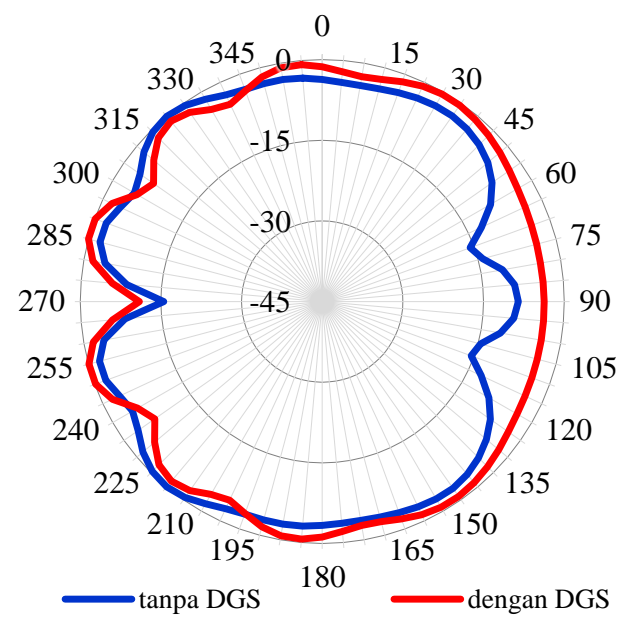

Gbr. 12 Hasil simulasi pola radiasi azimut ternormalisasi untuk antena SIW yang dirancang.

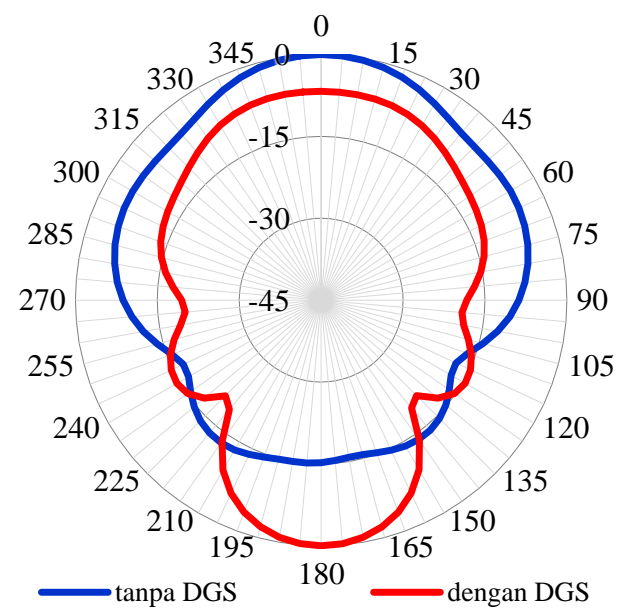

Gbr. 13 Hasil simulasi pola radiasi elevasi ternormalisasi untuk antena SIW yang dirancang.

gelombang pada dua arah, yaitu dari arah radiator (patch) sebagai elemen peradiasi dan dari arah ground plane melalui DGS.

\section{KeSimpUlan}

Proses desain, simulasi, dan studi parameter antena SIW dengan teknik DGS yang beroperasi pada frekuensi $L$-band telah dipaparkan pada makalah ini. Berdasarkan hasil simulasi dengan teknik DGS, lebar pita antena SIW dapat ditingkatkan dengan perolehan koefisien refleksi di bawah $-10 \mathrm{~dB}$ untuk rentang frekuensi 1,675 GHz hingga 2,25 GHz. Sementara itu, gain yang dihasilkan oleh antena SIW dengan DGS lebih besar jika dibandingkan dengan antena SIW tanpa DGS. Antena SIW dengan DGS memiliki pola radiasi bidirectional akibat adanya kebocoran (leaky wave) melalui DGS dari arah ground plane.

\section{UCAPAN TERIMA KASIH}

Terima kasih diucapkan kepada Sdr. Zenal Aripin atas bantuannya selama proses pengukuran antena di Laboratorium
Telekomunikasi dan Gelombang Mikro, Sekolah Teknik Elektro dan Informatika, Institut Teknologi Bandung.

\section{REFERENSI}

[1] G.Q. Luo, Z.F. Hu, L.X. Dong, dan L.L. Sun, "Planar Slot Antenna Backed by Substrate Integrated Waveguide Cavity," IEEE Antennas Wireless Propag. Letters., Vol. 7, hal. 236-239, Apr. 2008.

[2] F. Xu dan K. Wu, "Guided-wave and Leakage Characteristics Substrate Integrated Waveguide," IEEE Transactions on Microwave Theory and Techniques, Vol. 53, hal. 66-73, Jan. 2005.

[3] H. Uchimura, T. Takenoshita, dan M. Fujii, "Development of a Laminated Waveguide," IEEE Transactions on Microwave Theory and Techniques., Vol. 46, No. 12, hal. 2438-2443, Des. 1998.

[4] J. Hirokawa dan M. Ando, "Single-layer Feed Waveguide Consisting of Posts for Plane TEM Wave Excitation in Parallel Plates," IEEE Transactions on Antennas and Propagation, Vol. 46, No. 5, hal. 625630, Mei 1998

[5] M. Awida, S. Suleiman, dan A. Fathy, "Substrate-Integrated CavityBacked Patch Arrays: A Low-Cost Approach for Bandwidth Enhancement," IEEE Transactions on Antennas and Propagation, Vol. 59, No. 4, hal. 1155-1163, Jan. 2011.

[6] M. Chen, W. Che, dan S. He, "Bandwidth Enhancement of Substrate Integrated Waveguide (SIW) Slot Antenna with Parasitic Dipole," Proceedings of Asia-Pacific Microwave Conference, 2011, hal. 566-569.

[7] S. Yun, D.Y. Kim, dan S. Nam, "Bandwidth Enhancement of Cavitybacked Slot Antenna Using a Via-hole Above the Slot," IEEE Antennas Wireless Propagation Letters, Vol. 11, hal. 1092-1095, Agt. 2012.

[8] S. Yun, D.Y. Kim, dan S. Nam, "Bandwidth and Efficiency Enhancement of Cavity-backed Slot Antenna Using a Substrate Removal," IEEE Antennas and Wireless Propag. Letters, Vol. 11, hal. 1458-1461, Nov. 2012.

[9] M.M. Ulfah, Chairunnisa, dan A. Munir, "Bandwidth Enhancement of Substrate Integrated Waveguide Cavity-backed Slot Antenna," Proceedings of 3rd International Conference on Wireless and Telematics (ICWT), 2017, hal. 90-93.

[10] G.Q. Luo, Z.F. Hu, W.J. Li, X.H. Zhang, L.L. Sun dan J.F. Zheng, "Bandwidth-enhanced Low-profile Cavity-backed Slot Antenna by Using Hybrid SIW Cavity Modes," IEEE Transactions on Antennas and Propagation, Vol. 60, No. 4, hal. 1698-1704, Apr. 2012.

[11] A. Nouri dan G.R. Dadashzadeh, "A Compact UWB Band-Notched Printed Monopole Antenna with Defected Ground Structure," IEEE Antennas and Wireless Propagation Letters, Vol. 10, hal. 1178-1181, Okt. 2011.

[12] M.M. Ulfah, Chirunnisa, A.H. Wahyudi, dan A. Munir, "Slot and DGS Incorporation for Bandwidth Enhancement of Substrate Integrated Waveguide Antenna," 2018 Progress in Electromagnetics Research Symposium (PIERS-Toyama), 2018, hal. 1838-1841.

[13] B.J. Niu dan J.H. Tan, "Bandwidth Enhancement of Low-profile SIW Cavity Antenna with Bilateral Slots," Progress in Electromagnetics Research Letters, Vol. 82, hal. 25-32, 2019.

[14] Chairunnisa, M.M. Ulfah, A.A. Ginting, dan A. Munir, "ProximityCoupled Multiband Substrate Integrated Waveguide Antenna with Defected Ground Structure," Proc. of $4^{\text {th }}$ International Conference on Wireless and Telematics (ICWT), 2018, hal.1-4.

[15] D.M. Pozar, Microwave Engineering, $3^{\text {rd }}$ ed., Hoboken, USA: John Wiley \& Sons Inc., 2005.

[16] Y.J. Cheng, Substrate Integrated Antennas and Arrays, London, UK: CRC Press, 2016.

[17] G.Q. Luo, W. Hong, Q.H. Lai, K. Wu, dan L.L. Sun, "Design and Experimental Verification of Thin Frequency Selective Surface with Quasielliptic Bandpass Response," IEEE Transactions on Microwave Theory and Techniques, Vol. 55, No. 12, hal. 2481-2487, Des. 2007. 